\title{
Assessment of Alkali Activation Potential of a Polish Ferronickel Slag
}

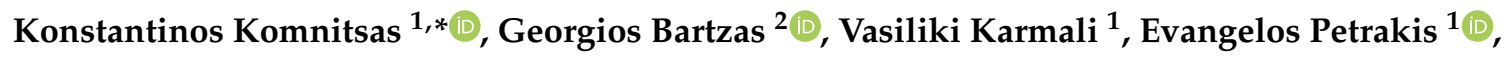 \\ Witold Kurylak ${ }^{3}$, Grzegorz Pietek ${ }^{3}$ and Jarosław Kanasiewicz ${ }^{4}$ \\ 1 School of Mineral Resources Engineering, Technical University of Crete, 73100 Chania, Greece; \\ vkarmali@isc.tuc.gr (V.K.); vpetraki@mred.tuc.gr (E.P.) \\ 2 National Technical University of Athens, School of Mining and Metallurgical Engineering, \\ 15780 Zografos, Athens, Greece; gbartzas@metal.ntua.gr \\ 3 Instytut Metali Nieżelaznych, ul. Generała Józefa Sowińskiego 5, 44-100 Gliwice, Poland; \\ witoldk@imn.gliwice.pl (W.K.); grzegorz.pietek@imn.gliwice.pl (G.P.) \\ 4 PROFIMA, ul. Bielawska 6/40, 02-511 Warsaw, Poland; kanasiewicz@interia.pl \\ * Correspondence: komni@mred.tuc.gr; Tel.: +30-28210-37686
}

Received: 7 February 2019; Accepted: 25 March 2019; Published: 28 March 2019

\begin{abstract}
In this study, the alkali activation potential of a Polish ferronickel slag (PS), for the production of inorganic polymers (IPs), is investigated. The effect of the main synthesis parameters, i.e., strength of the activating solution, consisting of $\mathrm{NaOH}$ and $\mathrm{Na}_{2} \mathrm{SiO}_{3}$ solutions and affecting $\left(\mathrm{SiO}_{2}+\mathrm{Al}_{2} \mathrm{O}_{3}\right) / \mathrm{Na}_{2} \mathrm{O}$ and other important molar ratios in the reactive paste, pre-curing period, curing temperature and time and ageing period was investigated. The structural integrity of the produced specimens was tested after their (i) immersion in distilled water and acidic solutions for a period of 7-30 days, and (ii) firing at temperatures between $200{ }^{\circ} \mathrm{C}$ and $1000{ }^{\circ} \mathrm{C}$. Several analytical techniques including $\mathrm{X}$-ray diffraction, $\mathrm{X}$-ray fluorescence, Fourier transform infrared spectroscopy, Differential scanning analysis-Thermogravimetry and Scanning Electron Microscopy were used for the characterization of the produced IPs. Results show that under the optimum synthesis conditions the IPs obtain compressive strength that exceeds $65 \mathrm{MPa}$. An innovative aspect of this study is that after heating at $400{ }^{\circ} \mathrm{C}$, the specimens acquire compressive strength of $115 \mathrm{MPa}$ and this indicates that they can be also used as fire resistant materials. This study highlights the potential of alkali activation for the valorization of a ferronickel slag and the production of IPs that can be used as binders or in several construction applications, thus improving the sustainability of the metallurgical sector.
\end{abstract}

Keywords: ferronickel slag; alkali activation; compressive strength; morphology

\section{Introduction}

Millions of tons of metallurgical slags, containing fine-grained silicate and glassy phases, are produced every year from the non-ferrous, ferrous and steel industry. Today, even though considerable quantities of slags are used in concrete production and other construction applications, large quantities are disposed on land and elsewhere, thus causing various environmental impacts [1-3].

By taking into account that several slags may be considered hazardous under the existing strict environmental regulations [4,5], the development of an integrated management scheme that valorizes slags, produces secondary products with higher added value, minimizes environmental impacts, and improves the sustainability of the metallurgical sector is under investigation [6-9].

Inorganic polymers (IPs) or geopolymers have an amorphous to semi-crystalline three dimensional alumino-silicate microstructure and chemical composition quite similar to zeolites $[10,11]$. They exhibit low permeability and high-unconfined compressive strength, low shrinkage, good 
resistance to acid attack, freeze-thaw cycles and fire, as well as good immobilization potential for several heavy metals within their structure [12-15]. In addition, some studies have been carried out to compare the environmental footprint of geopolymer and Portland concrete [16-18].

Inorganic polymers are produced through alkali activation. The source of IPs includes a broad range of virgin materials and industrial waste $[19,20]$. The process for the production of IPs starts with the dissolution of $\mathrm{Si}$ and $\mathrm{Al}$ from raw materials with the action of alkaline solutions and the formation of a gel that, after a relatively short setting time, hardens quickly. The presence of a silicate solution balances the $\mathrm{Si} / \mathrm{Al}$ atomic ratio in the IP paste and leads to the formation of homogeneous interconnected structures, which define their final physical, mechanical and thermal properties [21-25].

The alkali activation of various types of metallurgical slags, often in mixtures with other industrial wastes, for the production of IPs has been widely studied. The materials produced have diverse properties depending on the characteristics of the source materials, the additives, and the experimental conditions used. In this context, slags with varying content of $\mathrm{Fe}, \mathrm{Si}, \mathrm{Al}$ and $\mathrm{Ca}$ have been investigated, including ground granulated blast furnace slag mixed with fly ash [26-28], ferronickel (FeNi) slag $[2,29,30]$ or mixtures of FeNi slag, construction and demolition wastes and red mud [31], mixtures of steel slag and metakaolin or kaolin [32,33], slags from non-ferrous metallurgy [34], and mixtures of fly ash and lead slag [35].

The present experimental study aims to investigate the main factors affecting the alkali activation of an old and subjected to weathering Polish ferronickel slag, assess the structural integrity of the produced IPs when exposed to various environmental conditions, identify their potential toxicity, and determine whether they can be used in construction applications.

\section{Materials and Methods}

The slag, which was produced after pyrometallurgical treatment of nickel (Ni) lateritic ores, was collected from a waste dump at Szklary, Lower Silesia, in south-western Poland [36]. Mining was initiated in the area after the discovery of nickel deposits in 1890 and lasted until 1983. During the period of 1890-1920, ore was excavated using underground mining, while later surface mining techniques were applied. The Ni content in the ore varied between $1 \%$ and $4 \%$ in surface and deeper locations, respectively; it is mentioned that in some ore lenses, the Ni content was as high as $12 \%$. During the period of 1955-1983, about 4.6 million tons of ore were excavated, of which 2.9 million tons were treated pyrometallurgically to produce almost 20,000 $\mathrm{t}$ of nickel. Today, the mineable deposit is estimated at 14.64 million tons and the Ni that can be produced is estimated at 120 thousand tons; the cut-off grade of $\mathrm{Ni}$ in the ore is $0.8 \%$.

The as-received slag was pulverized using a Fritsch-Bico pulverizer and then characterized in terms of mineralogical and chemical composition. The particle size analysis of the ground slag was determined using a Mastersizer S (Malvern Instruments) analyser. A Bruker-AXS S2 Range Spectroscopic Fluorescence Spectrometer A (XRF-EDS) was used for chemical analysis, while the main mineralogical phases were identified through X-ray diffraction (XRD) using a Bruker D8 Advance diffractometer ( $\mathrm{Cu}$ tube, scanning range from $4^{\circ}$ to $70^{\circ} 2 \theta$, step $0.02^{\circ}$ and $2 \mathrm{~s} / \mathrm{step}$ ). Fourier transform infrared (FTIR) spectroscopy, using a Perkin Elmer Spectrum 1000 spectrometer, was used for the identification of the functional groups present in solid samples, while a Setaram LabSys Evo, TG-DTA-DSC analyzer was used to carry out differential thermal analysis and Thermogravimetry (DTA/TG). The identification of the morphology and structure of the raw material and the final products were identified by Scanning Electron Microscopy (SEM), using a JEOL 6380LV (USA) microscope equipped with an Oxford INCA energy dispersive X-ray spectrometer (EDS).

For the production of the IPs, the slag was mixed for about $10 \mathrm{~min}$, in a laboratory mixer under continuous slow stirring, with the alkaline activating solution, which was prepared by dissolving sodium hydroxide $(\mathrm{NaOH})$ anhydrous pellets (Sigma Aldrich) in distilled water to obtain the required molarity, namely $6,8,10$ and $12 \mathrm{~mol} \mathrm{~L}^{-1}(\mathrm{M})$, followed by the addition of sodium silicate solution $\left(\mathrm{Na}_{2} \mathrm{O}=7.5-8.5 \%, \mathrm{SiO}_{2}=25.5-28.5 \%\right.$, Merck). The activating solution, which was allowed to 
cool for $24 \mathrm{~h}$ prior to use, had molar ratios $\mathrm{SiO}_{2} / \mathrm{Na}_{2} \mathrm{O}$ equal to $0.37,0.26,0.21$ and 0.19 , while the $\mathrm{H}_{2} \mathrm{O} / \mathrm{Na}_{2} \mathrm{O}$ molar ratios were $19.03,14.31,11.16$ and 9.26 , respectively. The liquid/solid (L/S) ratio in the initial reactive paste varied slightly between 0.19 and 0.23 , depending on the conditions used in each case, to improve the flowability characteristics of the produced paste before casting. A typical average indicative composition of the starting mixture was (in wt $\%$ ): slag $82 \%$, $8 \mathrm{M} \mathrm{NaOH}$ solution $15 \%$ and $\mathrm{Na}_{2} \mathrm{SiO}_{3}$ solution $3 \%$; the $\mathrm{wt} \%$ of $\mathrm{Na}_{2} \mathrm{SiO}_{3}$ was kept constant in all tests. It is mentioned that these ratios are some of the lowest reported in the literature for similar studies.

The fresh paste was cast in cubic metal moulds of $5 \mathrm{~cm}$ edge, which were vibrated for a few minutes to remove air from the reactive mass and thus improve the strength of the final specimens. Pre-curing involved retention of the paste in the moulds at room temperature for a period of $6 \mathrm{~h}$ to $48 \mathrm{~h}$ to allow initiation of the alkali activating reactions, development of structural bonds and partial solidification. Then, the formed specimens were demoulded, sealed in plastic bags to prevent fast evaporation of the remaining water, cured at $40-80{ }^{\circ} \mathrm{C}$ in a laboratory oven (Jeio Tech ON-02G) for 24 or $48 \mathrm{~h}$ and allowed to cool. This configuration was based on the results obtained from a large number of previous studies investigating the alkali activation potential of several metallurgical wastes $[2,30]$. After ageing at room temperature $\left(20^{\circ} \mathrm{C}\right)$ for 7 days or 28 days, the compressive strength of the specimens was determined with the application of a MATEST C123N load frame. All tests were carried out in duplicate.

In order to study the structural integrity of the produced IPs, specimens obtained under the optimum conditions were immersed in distilled water and acidic solutions $\left(1 \mathrm{M} \mathrm{HCl}\right.$ and $\left.1 \mathrm{M} \mathrm{H}_{2} \mathrm{SO}_{4}\right)$ for 7, 15 and 30 days. Also, the thermal behavior of the IPs was evaluated after firing them in a laboratory oven (N-8L SELECTA) at temperatures between $200^{\circ} \mathrm{C}$ and $1000{ }^{\circ} \mathrm{C}$. The heating rate used was $5^{\circ} \mathrm{C} \mathrm{min}-1$, while the retention time at each temperature was very long, namely $6 \mathrm{~h}$. The specimens were naturally cooled in the oven prior to determination of their final compressive strength. Each experimental series was also carried out in duplicate.

The determination of the apparent density of selected IPs was carried out in accordance with BS EN 1936 (2006) [37]. Finally, the toxicity of the as-received slag as well as of the IPs produced was assessed by subjecting them to the EN 12457-3 test [38,39], involving leaching of $8 \mathrm{~L}$ per $\mathrm{kg}$ of material in distilled water for 24 hours. The leaching solutions were filtered using $0.45 \mu \mathrm{m}$ membrane filters and the concentration of the metals in the eluate was expressed as $\mathrm{mg} \mathrm{kg}^{-1}$ of dry slag or IP and compared with existing limits for disposal of wastes in various landfill types [40].

\section{Results and Discussion}

\subsection{Slag Characterisation}

The particle size distribution of the as-received slag after grinding revealed that the $90 \%$ passing size $\left(\mathrm{d}_{90}\right)$ of the material is $57.50 \mu \mathrm{m}$, which is considered adequately fine for efficient alkali activation and the production of IPs, as indicated in previous studies [41].

Table 1 shows the chemical composition of slag in the form of oxides, as derived by XRF. It is observed that the slag contains sufficient amounts of $\mathrm{SiO}_{2}(30.18 \%)$ and $\mathrm{Al}_{2} \mathrm{O}_{3}$ (7.6\%) for alkali activation, while the content of $\mathrm{Fe}_{2} \mathrm{O}_{3}$ and $\mathrm{CaO}$ is also high, $40.62 \%$ and $13 \%$, respectively.

Table 1. Chemical composition ( $w \mathrm{t} \%)$ of slag.

\begin{tabular}{llllllllllllll}
\hline $\mathrm{Fe}_{2} \mathrm{O}_{3}$ & $\mathrm{SiO}_{2}$ & $\mathrm{Al}_{2} \mathrm{O}_{3}$ & $\mathrm{Cr}_{2} \mathrm{O}_{3}$ & $\mathbf{M g O}$ & $\mathrm{NiO}$ & $\mathbf{K}_{2} \mathrm{O}$ & $\mathrm{Na}_{2} \mathrm{O}$ & $\mathrm{TiO}_{2}$ & $\mathrm{CoO}$ & $\mathbf{M n O}$ & $\mathrm{CaO}$ & $\mathbf{P}_{2} \mathrm{O}_{5}$ & $\mathrm{Total}$ \\
\hline 40.62 & 30.18 & 7.60 & 1.98 & 1.80 & 0.95 & 0.89 & 0.44 & 0.69 & 0.03 & 0.28 & 13.0 & 0.02 & 98.48 \\
\hline
\end{tabular}

The quality of this slag is comparable with that of Larco S.A slag, derived from pyrometallurgical treatment of Greek laterites and used in a previous study for the synthesis of IPs [41]. The only major difference is that Larco slag has much lower $\mathrm{CaO}$ content, 3.73\%. 


\subsection{Factors Affecting IP Synthesis}

\subsubsection{Effect of $\mathrm{NaOH}$ Molarity, Selected Molar Ratios in the Reactive Paste and Curing Temperature}

Figure 1 shows the compressive strength of the IPs produced after a curing period of $24 \mathrm{~h}$ and an ageing period of 7 days as a function of $\mathrm{NaOH}$ molarity $(6-12 \mathrm{M})$ and curing temperature $\left(40^{\circ} \mathrm{C}\right.$ or $\left.80^{\circ} \mathrm{C}\right)$. It is seen that the effect of temperature is considered marginal for all $\mathrm{NaOH}$ concentrations tested; this indicates, in terms of heating requirements, that the process is energy efficient. On the other hand, the compressive strength of the produced IPs increases slightly and reaches its maximum value, 67.0 MPa, when the $\mathrm{NaOH}$ molarity increases from 6 to $8 \mathrm{M}$, whereas it drops substantially when higher $\mathrm{NaOH}$ molarities (10-12 M) are used. The fact that an optimum $\mathrm{NaOH}$ concentration exists has been also noted in several earlier studies involving alkali activation of slags and other industrial wastes $[3,42,43]$. When high $\mathrm{NaOH}$ molarity is used, unreacted $\mathrm{OH}^{-}$may remain in the paste and the produced specimens cannot acquire the maximum strength. Overall, for this specific slag, it is deduced that $\mathrm{NaOH}$ molarity is a much more important factor than curing temperature during IP synthesis. Finally, it is mentioned that the water loss during curing at $80{ }^{\circ} \mathrm{C}$ is identical $(1.9 \%)$ when $\mathrm{NaOH}$ molarity is $6 \mathrm{~mol} \mathrm{~L}^{-1}$ or $8 \mathrm{~mol} \mathrm{~L}^{-1}$ and increases to $2.5 \%$ or $3.1 \%$ when the molarity used is $10 \mathrm{~mol} \mathrm{~L}^{-1}$ and $12 \mathrm{~mol} \mathrm{~L}^{-1}$, respectively.

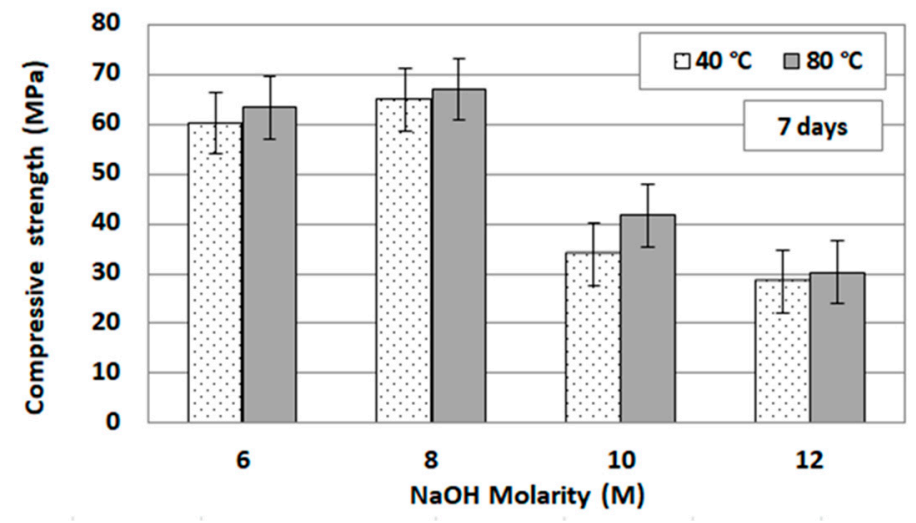

Figure 1. Effect of $\mathrm{NaOH}$ molarity in relation to curing temperature on the compressive strength of the produced IPs (curing temperature $40^{\circ} \mathrm{C}$ or $80^{\circ} \mathrm{C}$, ageing period seven days, pre-curing and curing time $24 \mathrm{~h}$; error bars denote standard deviation of measurements obtained from three specimens).

In order to further elucidate these findings, the molar ratios of selected phases present in the initial reactive paste for each $\mathrm{NaOH}$ molarity used, are calculated and presented in Table 2. In this table, the compressive strength of IPs cured at $80^{\circ} \mathrm{C}$ (shown in Table 1) are also given for comparison.

Table 2. Molar ratios of selected phases present in the reactive paste.

\begin{tabular}{cccccc}
\hline $\begin{array}{c}\mathbf{N a O H} \\
\text { Molarity (M) }\end{array}$ & $\begin{array}{c}\text { Compressive Strength } \\
(\mathbf{M P a})\end{array}$ & $\left(\mathbf{S i O}_{\mathbf{2}}+\mathbf{A l}_{\mathbf{2}} \mathbf{O}_{3}\right) / \mathbf{N a}_{\mathbf{2}} \mathbf{O}$ & $\mathbf{H}_{\mathbf{2}} \mathbf{O} / \mathbf{N a} \mathbf{O} \mathbf{O}$ & $\mathbf{N a} / \mathbf{A l}$ & $\mathbf{F e}_{\mathbf{2}} \mathbf{O}_{3} / \mathbf{N a}_{2} \mathbf{O}$ \\
\hline 6 & 63.3 & 11.9 & 16.3 & 0.7 & 5.1 \\
8 & 67.0 & 8.6 & 12.9 & 0.9 & 3.7 \\
10 & 41.7 & 6.8 & 10.3 & 1.2 & 2.9 \\
12 & 30.2 & 6.4 & 8.5 & 1.3 & 2.7 \\
\hline \multicolumn{5}{c}{}
\end{tabular}

As shown in Table 2, when the activator concentration increases, given that the $\mathrm{wt} \%$ addition of $\mathrm{Na}_{2} \mathrm{SiO}_{3}$ solution is low and identical in all tests, the molar ratios $\left(\mathrm{SiO}_{2}+\mathrm{Al}_{2} \mathrm{O}_{3}\right) / \mathrm{Na}_{2} \mathrm{O}$ decrease in the reactive paste and thus higher degree of hydrolysis and dissolution of silicon, aluminium and iron that polymerize/polycondensate to form IPs with higher strength is anticipated. This is confirmed by our data, which show that when the $\mathrm{NaOH}$ molarity increases from $6 \mathrm{M}$ to $8 \mathrm{M}$, the compressive 
strength also increases slightly $(\sim 5 \%)$. Lower molar ratios, obtained when higher $\mathrm{NaOH}$ molarities are used, result in excess of activator in the paste, which may not fully react with solid particles or require much longer time for reaction and thus the specimens acquire lower strength. This conclusion is also supported by the values of the $\mathrm{Na} / \mathrm{Al}$ ratio in the reactive paste. Optimum ratios indicate the presence of sufficient $\mathrm{OH}^{-}$, which accelerate polycondensation, whereas if ratios get bigger than a specific value, the compressive strength will drop. As mentioned in a recent study and several other research works, an optimum $\mathrm{Na} / \mathrm{Al}$ ratio close to one is required for the synthesis of IPs with high strength [44]. Regarding the effect of the molar ratio $\mathrm{Fe}_{2} \mathrm{O}_{3} / \mathrm{Na}_{2} \mathrm{O}$, it is seen from Table 2 that obviously this ratio decreases as the molarity of $\mathrm{NaOH}$ solution increases. The role of $\mathrm{Fe}$, whose content is high in several slags of the non-ferrous and steel industry, cannot be easily elucidated. Good insights into the behavior of $\mathrm{Fe}$ are provided in recent studies, which indicate that $\mathrm{Fe}^{2+}$ may be oxidized to $\mathrm{Fe}^{3+}$ during alkaline activation in the inorganic polymer binder, or incorporated into the polysialate ( $\mathrm{Si}-\mathrm{O}-\mathrm{Al}$ ) as network modifier or even participate in carbonation reactions [45,46]. However, in our case, no efflorescence was noticed on any of the produced specimens.

\subsubsection{Effect of Ageing Period}

Figure 2 shows the effect of ageing period on the compressive strength of the produced IPs. It is seen from this data that the ageing period has practically no effect on the compressive strength and the values obtained are almost identical and within the measurement error; the highest value recorded was $71.4 \mathrm{MPa}$, when IPs were produced using $8 \mathrm{M} \mathrm{NaOH}$ after curing at $80^{\circ} \mathrm{C}$ and ageing for 28 days. This means that the alkali activation reactions are fast and almost completed during curing and ageing for seven days, in contrast to the reactions involved in concrete production, which progress for a period of 28 days after casting and result in additional strength gain. The only exception shown was in the case where $12 \mathrm{M} \mathrm{NaOH}$ solution was used as activating solution and some of the excess $\mathrm{NaOH}$ reacts over the remaining period so that the final compressive strength increases to $47.8 \mathrm{MPa}$ after 28 days ( $58 \%$ increase). As mentioned earlier, the only parameter that varied significantly in our tests was the molarity of the $\mathrm{NaOH}$ solution, whereas the $\mathrm{wt} \%$ addition of $\mathrm{Na}_{2} \mathrm{SiO}_{3}$ was kept equal in all tests and the L/S ratio in the reactive paste was very low. Prolonged ageing periods normally improve compressive strength [2,44], but in our study this was not the case even when different mixing configurations were used (data not shown).

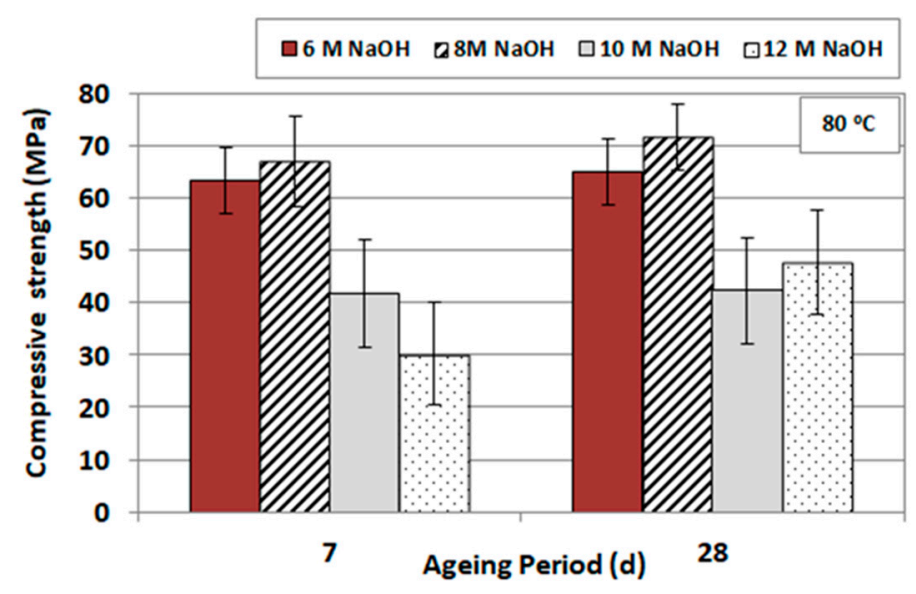

Figure 2. Effect of ageing period (in days) in relation to $\mathrm{NaOH}$ molarity on the compressive strength of the produced IPs (curing temperature $80{ }^{\circ} \mathrm{C}$, pre-curing and curing time $24 \mathrm{~h}$; error bars denote standard deviation of measurements obtained from three specimens).

\subsubsection{Effect of Pre-Curing and Curing Period}

Figure $3 a, b$ show the effect of pre-curing and curing period on the compressive strength of the produced IPs, respectively. The duration of pre-curing defines the extent to which reactions involved 
in alkali activation of the raw materials, depending on the L/S ratio and the strength of the activating solution, proceed so that bonds are developed and specimens harden and acquire early strength.

It is seen in Figure $3 a$ that for a pre-curing period of $6 \mathrm{~h}$ or $24 \mathrm{~h}$, the produced IPs obtain marginally better compressive strength when $8 \mathrm{M} \mathrm{NaOH}$ is used. If the pre-curing period becomes $48 \mathrm{~h}$, the use of $6 \mathrm{M} \mathrm{NaOH}$ results in IPs with higher strength $(78.4 \mathrm{MPa})$, almost $28 \%$ increase in comparison with the pre-curing period of $24 \mathrm{~h}$. The use of $10 \mathrm{M} \mathrm{NaOH}$ results in IPs with lower compressive strength, regardless of the pre-curing period used. Based on this data, we selected $24 \mathrm{~h}$ as optimum pre-curing period.

Figure $3 \mathrm{~b}$ shows that when the molarity of $\mathrm{NaOH}$ is $8 \mathrm{M}$, the curing temperature $80^{\circ} \mathrm{C}$ and the ageing period $24 \mathrm{~h}$, the optimum curing period is $24 \mathrm{~h}$. The same graph also indicates that longer curing periods, when high molarity and temperature are used, has an adverse effect on the compressive strength of the produced IPs. This loss of strength is mainly linked to (i) the lack of sufficient amount of water, which is necessary for polycondensation reactions and (ii) the presence of unreacted alkaline solution, factors which affect the mobility of ions in the matrix and also create internal stresses [47].

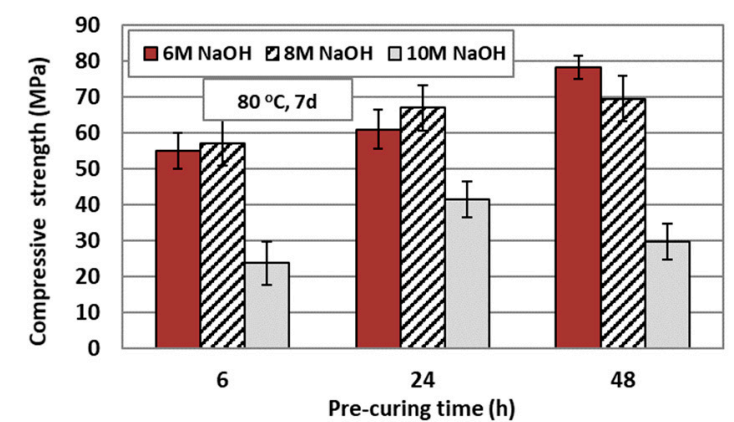

(a)

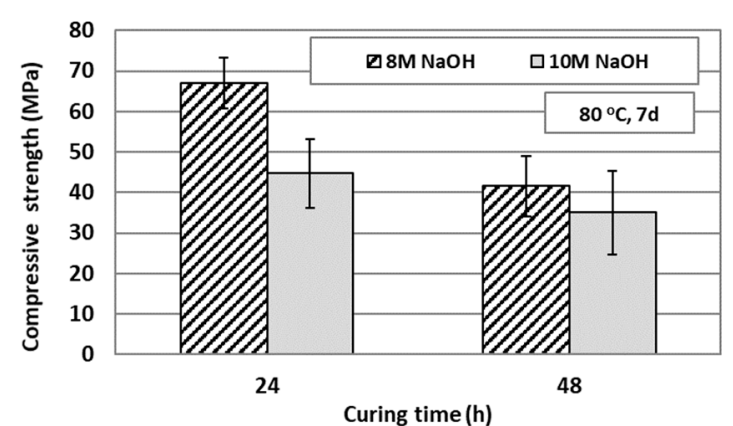

(b)

Figure 3. Effect of (a) pre-curing time and (b) curing time and $\mathrm{NaOH}$ molarity on the compressive strength of inorganic polymer (curing temperature $80^{\circ} \mathrm{C}$, curing time $24 \mathrm{~h}$, ageing period seven days; the pre-curing time in (b) is $24 \mathrm{~h}$; error bars denote standard deviation of measurements obtained from three specimens).

\subsection{Structural Integrity of IPS}

\subsubsection{Effect of High-Temperature Firing}

Figure 4 illustrates the effect of firing of IPs, for a period of $6 \mathrm{~h}$, over a temperature range of 200-1000 ${ }^{\circ} \mathrm{C}$ on their compressive strength. The specimens tested were produced using activating solution consisting of $8 \mathrm{M} \mathrm{NaOH}$ and $\mathrm{Na}_{2} \mathrm{SiO}_{3}$, curing temperature of $80^{\circ} \mathrm{C}$, curing period $24 \mathrm{~h}$ and ageing period seven days. The compressive strength of the control specimen, which was not subjected to firing, is also shown for comparison. In addition, Table 3 shows some selected properties, namely shrinkage (\%), mass loss (\%) and apparent density $\left(\mathrm{g} \mathrm{cm}^{-3}\right)$ of the fired specimens.

It is seen from this data that the compressive strength of the specimens increases substantially after firing up to $400{ }^{\circ} \mathrm{C}$ and then decreases sharply. The increase of the compressive strength after firing at $400{ }^{\circ} \mathrm{C}$ to $115 \mathrm{MPa}$ may be attributed to oxidation of fayalite and magnetite of the PS and the increase in the quantity of several phases as shown in the XRD patterns (see below in text). This behavior has also been observed in a study by Onisei et al. [48], where the IPs produced from alkaline activation of a fayalitic slag $\left(\mathrm{Fe}_{2} \mathrm{O}_{3} 49.6 \%, \mathrm{SiO}_{2} 27.1 \%, \mathrm{Al}_{2} \mathrm{O}_{3} 6.8 \%, \mathrm{ZnO} 8.4 \%\right.$ and $\left.\mathrm{CaO} 1.6 \%\right)$ exhibited after firing at $500{ }^{\circ} \mathrm{C}$ an increase in strength by almost $30 \%$ to $105 \mathrm{MPa}$, regardless of the addition of $5 \%$ or $10 \%$ analytical grade $\mathrm{Al}_{2} \mathrm{O}_{3}$ in the starting mixture. This increase in strength was attributed to the formation of new phases, including laihunite $\left[\mathrm{Fe}^{2+} \mathrm{Fe}^{3+}{ }_{2}\left(\mathrm{SiO}_{4}\right)_{2}\right]$ as the result of oxidation of fayalite, as well as sodium aluminum silicate $\left(\mathrm{NaAlSiO}_{4}\right)$, hematite, magnetite and spinel hercynite $\left(\mathrm{FeAl}_{2} \mathrm{O}_{4}\right)$. The compressive strength of the IPs after firing at $1000{ }^{\circ} \mathrm{C}$ was extremely low, while the specimens showed a volumetric expansion of $7.1 \%$ and were severely damaged. This sharp drop in strength after 
firing in very high temperatures is due to dehydroxylation of silanol ( $\mathrm{Si}-\mathrm{OH})$ and aluminol $(\mathrm{Al}-\mathrm{OH})$ groups that causes development of cracks and pores [49].

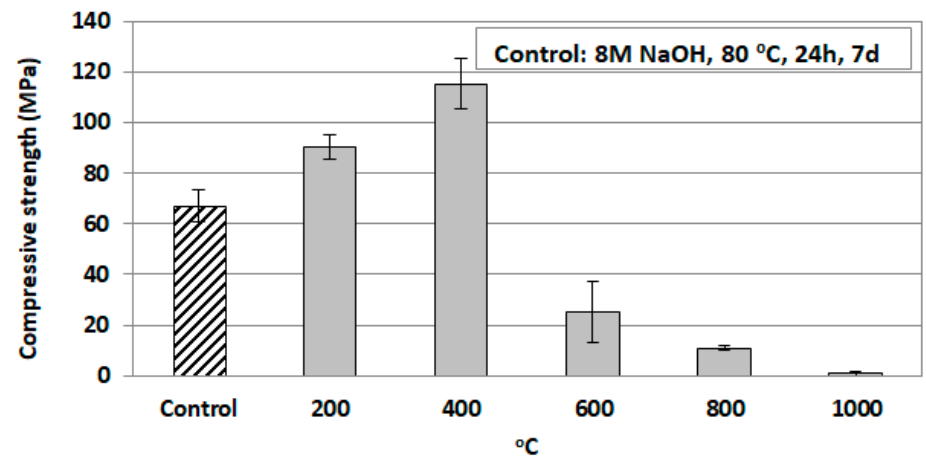

Figure 4. Evolution of compressive strength of selected IPs when fired at high temperatures (the compressive strength of control IP was determined after 7 days of ageing); error bars denote standard deviation of measurements obtained from three specimens.

Table 3. Selected properties of the fired specimens.

\begin{tabular}{ccccc}
\hline Temperature $\left({ }^{\circ} \mathbf{C}\right)$ & $\begin{array}{c}\text { Compressive } \\
\text { Strength (MPa) }\end{array}$ & Shrinkage (\%) & Mass Loss (\%) & Apparent Density $\left(\mathbf{g ~ c m}^{-3}\right)$ \\
\hline 200 & 90 & 4.0 & 5.1 & 2.2 \\
400 & 115 & 4.8 & 7.3 & 2.7 \\
600 & 25 & 3.6 & 9.6 & 2.0 \\
800 & 11 & 2.2 & 10.2 & 1.8 \\
1000 & 2 & -7.1 & $\mathrm{NM}^{1}$ & $\mathrm{NM}$ \\
\hline \multicolumn{5}{c}{}
\end{tabular}

Other factors that contributed to the increase in strength after firing at $400{ }^{\circ} \mathrm{C}$ are the volumetric shrinkage by $4.8 \%$ (Table 3), which is the highest at this temperature, and the increase in density to $2.7 \mathrm{~g} \mathrm{~cm}^{-3}$. The bigger changes seen, mainly for shrinkage and mass loss, after firing at temperatures higher than $600{ }^{\circ} \mathrm{C}$ are mainly due to phase transformations. These properties were not measured for the IP fired at $1000{ }^{\circ} \mathrm{C}$, since as mentioned earlier, it suffered severe damage. The increase in strength of the IPs produced in the present study after firing at $400{ }^{\circ} \mathrm{C}$ is a very important finding and shows that they can be potentially used as fire resistant materials and replace or coat concrete in specific construction applications; for example, in tunnels, thus allowing more time for rescue teams to intervene in case of fire. Similar, but noticeably smaller increase was also reported in earlier studies investigating the potential of a Greek ferronickel slag for the production of IPs [49,50].

\subsubsection{Effect of Immersion of IPs in Distilled Water or Acidic Solutions}

Figure 5 shows the compressive strength of IPs, produced under the conditions of molarity $\mathrm{NaOH}$ $8 \mathrm{M}$, heating $80^{\circ} \mathrm{C}$, curing period 24 hours and ageing period seven days, when immersed in distilled water or acidic solutions ( $1 \mathrm{M} \mathrm{HCl}$ and $1 \mathrm{M} \mathrm{H}_{2} \mathrm{SO}_{4}$ ) for 7,15 and 30 days. The compressive strength of control specimens is also provided for comparison. It is seen that the immersion of IPs in distilled water, even for a period of 30 days, has a relatively minor effect on their compressive strength. Also, the IPs retain a very good strength, varying between $33.8 \mathrm{MPa}$ and $36.5 \mathrm{MPa}$, even when immersed in $1 \mathrm{M} \mathrm{HCl}$ and $\mathrm{H}_{2} \mathrm{SO}_{4}$ solutions for a period of 30 days. The maximum mass loss of the IPs immersed in distilled water, $\mathrm{H}_{2} \mathrm{SO}_{4}$ and $\mathrm{HCl}$ solutions was $0.9 \%, 3.2 \%$ and $5.6 \%$ respectively, which is considered as low to very low in all cases. Earlier studies carried out in our laboratory confirm the higher mass loss of various IPs when immersed in $\mathrm{HCl}$ solution. It is also mentioned that the final $\mathrm{pH}$ of the solutions containing distilled water, $\mathrm{HCl}$ and $\mathrm{H}_{2} \mathrm{SO}_{4}$ after immersion of the specimens for 30 days was 11.0, 2.7 and 1.7 respectively. These results indicate that the IPs respond well and exhibit very good structural integrity in corrosive environments. 


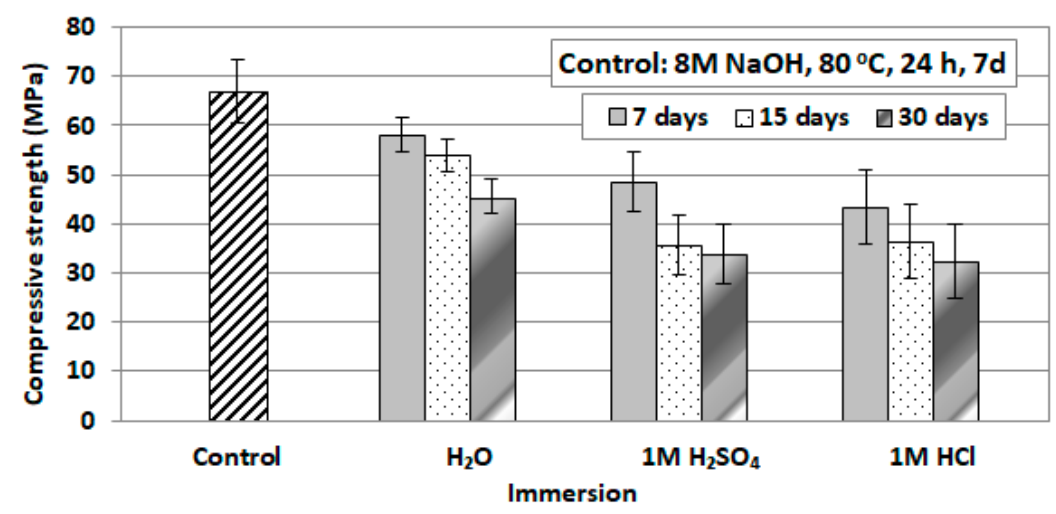

Figure 5. Evolution of the compressive strength of selected specimens immersed in water or acidic solutions for a period of 7 to 30 days (the compressive strength of the control IP is obtained after seven days; error bars denote standard deviation of measurements obtained from three specimens).

\subsection{Morphology-Microstructure of Inorganic Polymers}

Figure 6 presents the XRD pattern of PS and selected IPs, namely the one produced under the conditions of molarity $\mathrm{NaOH} 8 \mathrm{M}$, curing temperature $80^{\circ} \mathrm{C}$ and curing period $24 \mathrm{~h}$, as well as those immersed in $1 \mathrm{M} \mathrm{HCl}$ for 30 days or fired at $400{ }^{\circ} \mathrm{C}$. It is seen from this figure that the main mineralogical phases present in PS are quartz $\left(\mathrm{SiO}_{2}\right)$, hedenbergite $\left(\mathrm{Ca}(\mathrm{Fe}, \mathrm{Mg})\left(\mathrm{SiO}_{3}\right)_{2}\right)$, fayalite $\left(\mathrm{Fe}_{2} \mathrm{SiO}_{4}\right)$, diopside $\left(\mathrm{CaMgSi}_{2} \mathrm{O}_{6}\right)$ and magnetite $\left(\mathrm{Fe}_{3} \mathrm{O}_{4}\right)$, while hatrurite $\left(\mathrm{Ca}_{3} \mathrm{SiO}_{5}\right)$ is present as a minor phase. In addition, PS has a high amorphous content $(\sim 4 \%)$, which is indicated by the broad hump shown between $2 \theta$ $25-40^{\circ}$, and is typical for several metallurgical slags $[49,50]$. As seen in Figure $6 \mathrm{~b}-\mathrm{d}$, no new visible major crystalline phases for the selected IPs were detected. However, the intensities of some crystalline phases, namely fayalite, hedenbergite and diopside increases in the IP after firing at $400{ }^{\circ} \mathrm{C}$ and this may explain the noticeable increase of its compressive strength.

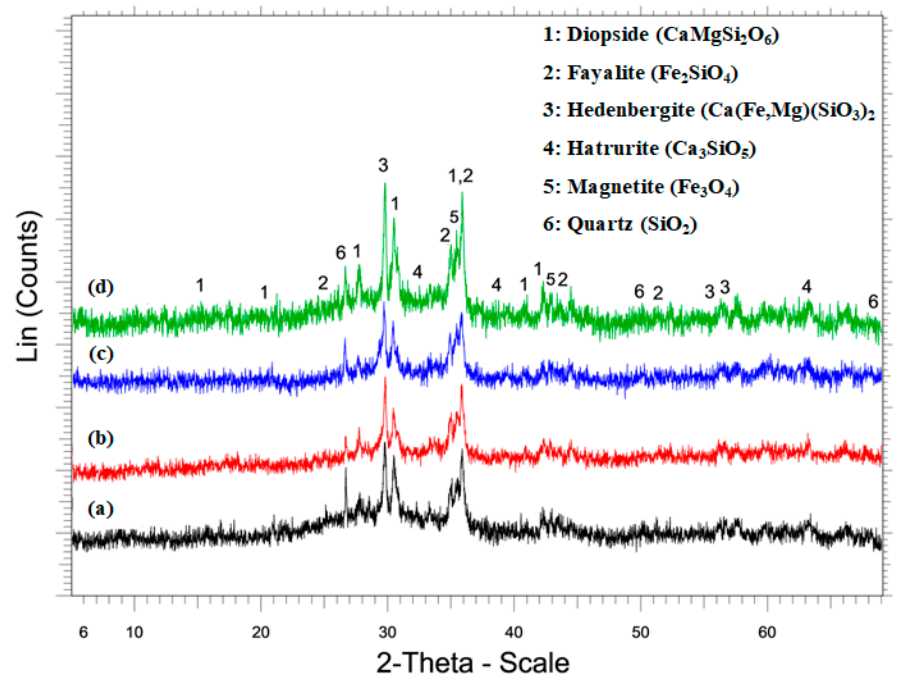

Figure 6. XRD patterns of (a) raw PS, (b) IP produced after alkali activation with $8 \mathrm{M} \mathrm{NaOH}$, (c) IP immersed in $1 \mathrm{M} \mathrm{HCl}$ for 30 days and (d) IP fired at $400{ }^{\circ} \mathrm{C}$.

The FTIR spectra of raw PS and selected IPs are shown in Figure 7. In line with the XRD data, the spectrum of the raw PS presents the characteristic peaks of Ca-Fe-Mg-silicate-based slags dominated by fayalite, diopside and hedenbergite, with bands seen at $828 \mathrm{~cm}^{-1}, 872 \mathrm{~cm}^{-1}$ and $948 \mathrm{~cm}^{-1}$ [45,46,51-53]. The first band results from the v1 mode (symmetric stretch), while the others correspond to the asymmetric stretching vibrations of $\mathrm{SiO}_{4}$ (v3 mode). An additional peak associated with the stretching vibrations of Si-O bands of diopside is also seen at $668 \mathrm{~cm}^{-1}$ [54]. The peak seen 
at $472 \mathrm{~cm}^{-1}$ in Figure $7 \mathrm{a}, \mathrm{b}$ (raw PS and IP produced using $8 \mathrm{M} \mathrm{NaOH}$ ) is ascribed to the overlapping $\mathrm{Si}-\mathrm{O}-\mathrm{Si}$ and $\mathrm{O}-\mathrm{Mg}-\mathrm{O}$ bending vibrations $[55,56]$. It is seen that this rocking band disappears after firing at $400{ }^{\circ} \mathrm{C}$ (Figure $7 \mathrm{~d}$ ), thus indicating that phase transformations took place and may have resulted in the increase of the compressive strength. The strong single peak at $1016 \mathrm{~cm}^{-1}$ shown in Figure $7 \mathrm{~b}$ (IP produced using $8 \mathrm{M} \mathrm{NaOH}$ ) reveals the formation of reaction products in the IPs after exposure to highly alkaline solution $[41,57,58]$. The structural reorganization as result of the alkaline activation is more noticeable in the broader bands shown in the same region $\left(800-1200 \mathrm{~cm}^{-1}\right)$ for the IPs immersed in $\mathrm{HCl}$ solution or fired at $400{ }^{\circ} \mathrm{C}$ (Figure $7 \mathrm{c}, \mathrm{d}$, respectively). The weaker band at $1634 \mathrm{~cm}^{-1}$ in the raw PS and the sharper peaks seen at $1650 \mathrm{~cm}^{-1}, 1636 \mathrm{~cm}^{-1}$ and $1644 \mathrm{~cm}^{-1}$ in IPs belong to the characteristic bending vibrations of $\mathrm{H}-\mathrm{O}-\mathrm{H}$ [59-61]. The intense absorption bands at $\sim 1410 \mathrm{~cm}^{-1}$ and $\sim 1490 \mathrm{~cm}^{-1}$ shown only in the IPs are attributed to stretching vibrations of O-C-O bonds due to carbonation of the remaining Na-silicate [59,62]. Moreover, the notable bands observed in the raw PS and IP produced using $8 \mathrm{M} \mathrm{NaOH}$ at $3744 \mathrm{~cm}^{-1}$ and $3756 \mathrm{~cm}^{-1}$, respectively (Figure $7 \mathrm{a}, \mathrm{b}$ ) are typical for the $\mathrm{OH}$-stretching region. However, the presence of water is more evident in all IPs since a quite wide absorption band region appeared between $3000 \mathrm{~cm}^{-1}$ and $3700 \mathrm{~cm}^{-1}$ belonging to stretching vibrations of $\mathrm{OH}$ groups [52], as result of the hydration processes that took place during alkali activation.

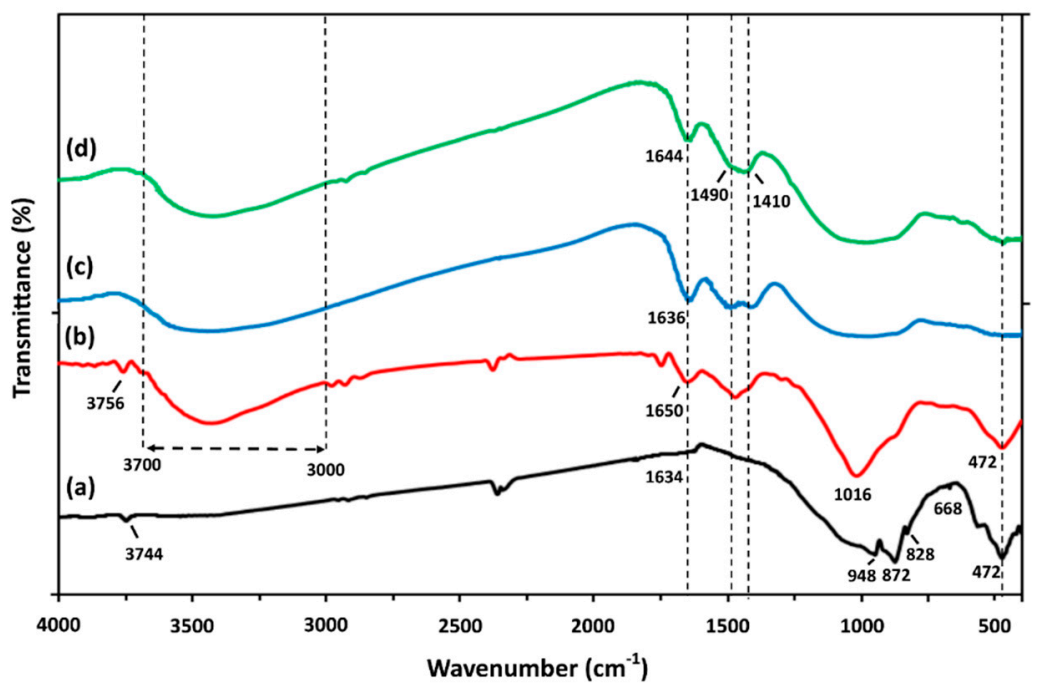

Figure 7. FTIR spectra of (a) raw slag, (b) IP produced after alkali activation with $8 \mathrm{M} \mathrm{NaOH}$, (c) IP immersed in $1 \mathrm{M} \mathrm{HCl}$ for 30 days and (d) IP fired at $400{ }^{\circ} \mathrm{C}$.

The behavior of the raw slag and selected IPs, namely the one produced after alkaline activation using $8 \mathrm{M} \mathrm{NaOH}$, curing temperature of $80^{\circ} \mathrm{C}$ and curing period of $24 \mathrm{~h}$ (control IP) as well as after firing at $400{ }^{\circ} \mathrm{C}$ was investigated through DTA/TG analysis (Figure 8a-c). In general, TG-curves show that the initial mass of the samples decreases as a result of dehydration of free (below $200{ }^{\circ} \mathrm{C}$ ) and chemically bound water up to $400{ }^{\circ} \mathrm{C}$ for raw PS (Figure 8a) and $570{ }^{\circ} \mathrm{C}$ for IPs (Figure $8 \mathrm{~b}, \mathrm{c}$ ). More specifically, Figure 8a shows a clearly visible peak at $742{ }^{\circ} \mathrm{C}$ associated to significant mass gain $(\sim 2.3 \%)$ of the PS, which can be attributed to the oxidation of fayalite to hematite and silica [53]. This exo-effect is characterized by a continuous increase in mass for the raw PS and involves a four-stage mechanism, i.e., (i) oxidation of magnetite and formation of metastable spinel $\left(\gamma-\mathrm{Fe}_{2} \mathrm{O}_{3}\right)$, (ii) transformation of $\gamma-\mathrm{Fe}_{2} \mathrm{O}_{3}$ into the stable $\alpha-\mathrm{Fe}_{2} \mathrm{O}_{3}$; (iii) oxidation and decomposition of fayalite $\left(2 \mathrm{FeO} \cdot \mathrm{SiO}_{2}\right)$, (iv) decomposition of the residual fayalite and polymorphic transformations of the silicate and iron phases [63]. On the other hand, the endothermic peak shown at $468^{\circ} \mathrm{C}$ in the raw PS is related to dehydroxylation/condensation processes [64], which result in a slight mass loss $(\sim 0.4 \%)$ due to the release of residual moisture. 
Figure $8 \mathrm{~b}, \mathrm{c}$ show that similar TG-curves were obtained for the two selected IPs as a result of alkali-activation. The control IP (Figure 8 b) shows a weight loss $\sim 7 \%$, observed below $200{ }^{\circ} \mathrm{C}$, which is mainly attributed to the dehydration of the calcium/magnesium-rich silicate gel. The remaining more strongly bound water evaporates after heating above $400{ }^{\circ} \mathrm{C}$ and results in an additional $3 \%$ weight loss. Heating in higher temperatures results in a minor weight increase $(\sim 0.7 \%)$, attributed to oxidation reactions that took place in the iron-rich phases i.e., fayalite and magnetite $[52,65]$. Regarding the IP fired at $400{ }^{\circ} \mathrm{C}$, a four-time lower overall decrease in mass is observed compared to control IP $(3.3 \%$ vs. $12.1 \%$ ), thus indicating that more pronounced alkali-activation processes dominated the formation of the geopolymeric gel. The latter also explains the structural stability of this IP, which is reflected by its noticeable increase in strength $(115 \mathrm{MPa})$.

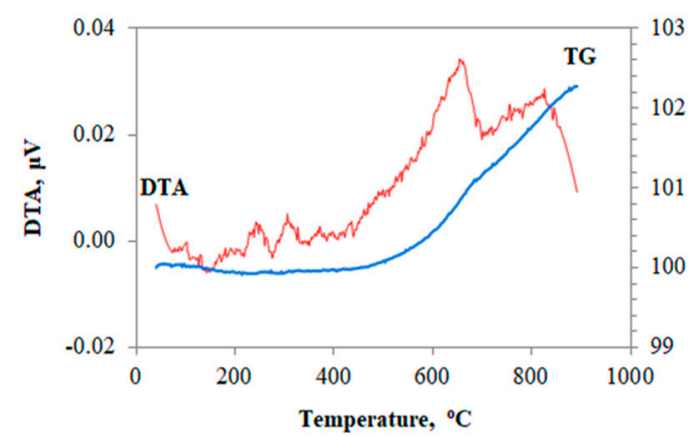

(a)

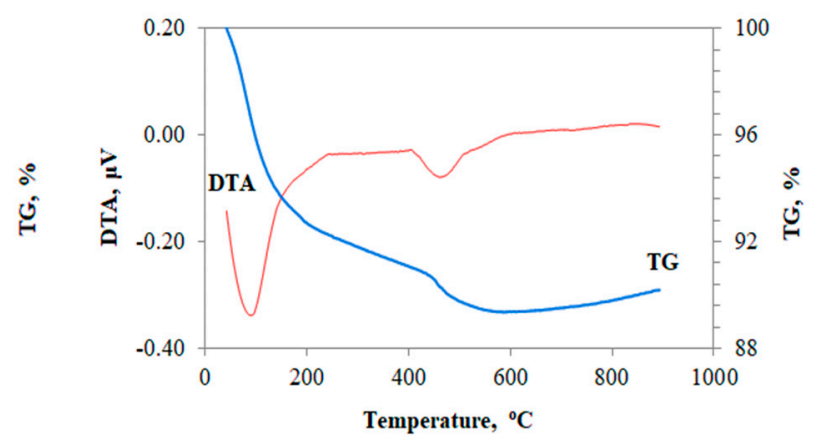

(b)

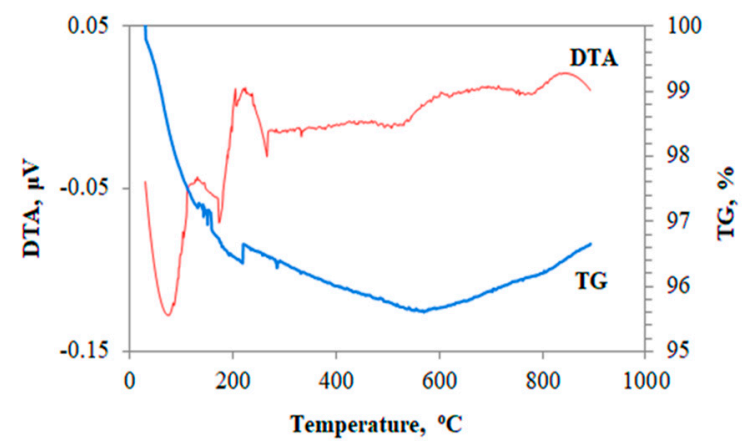

(c)

Figure 8. DTA-TG analysis of (a) raw slag, (b) control IP produced using $8 \mathrm{M} \mathrm{NaOH}$ and (c) IP fired at $400{ }^{\circ} \mathrm{C}$.

As shown in XRD analysis, SEM examination of PS surface by SEM/EDS (Figure 9a) revealed a glassy morphology with sharp edges that is heterogeneous in size and dominated by large quartz, diopside and weathered fayalite crystals $(>50 \mu \mathrm{m}$ long) along with small spherical grains $(<15 \mu \mathrm{m})$ of magnetite. According to EDS point analyses, other (inter)metallic phases such as chromite $\left(\mathrm{FeCr}_{2} \mathrm{O}_{4}\right)$ and awaruite $\left(\mathrm{Ni}_{3} \mathrm{Fe}\right)$ were also detected in minor quantities as small single intergrown drops and inclusions, respectively [36]. Furthermore, several parallel laths/seams of Cr-spinel ( $2 \mu \mathrm{m}$ thick) embedded in clinopyroxene (diopside) matrix were identified containing up to $5.2 \% \mathrm{Cr}$. 


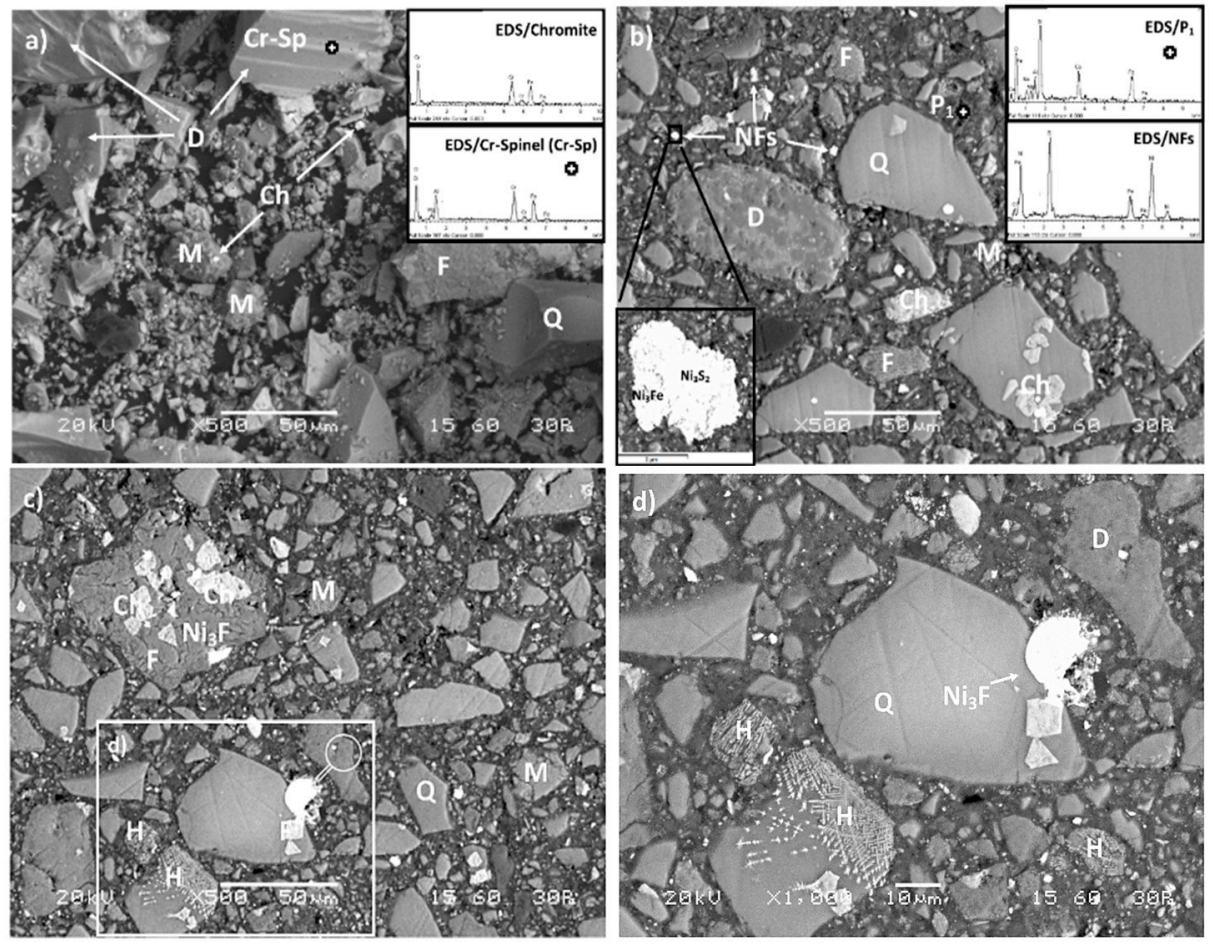

Figure 9. Back-scattered electron images of (a) raw PS surface and cross-sections of selected IPs after (b) alkali activation with $8 \mathrm{M} \mathrm{NaOH}$, and (c,d) firing at $400{ }^{\circ} \mathrm{C}$. EDS spectra show in several spot locations the presence of (inter)metallic phases, the formation of mixed aggregates and newly formed phases (Q: Quartz, D: Diaspore, F: Fayalite, M: Magnetite, H: Hematite, NFs: Ni-Fe sulfides, Ch: Chromite, Cr-Sp: Cr-Spinel).

After alkali activation of PS with $8 \mathrm{M} \mathrm{NaOH}$ at $80^{\circ} \mathrm{C}$ (Figure $9 \mathrm{~b}$ ) or firing at $400{ }^{\circ} \mathrm{C}$ (Figure $9 \mathrm{c}, \mathrm{d}$ ), a moderate to highly homogenous and dense glassy matrix (dark color) is formed between PS grains (bright color) and observed in the geopolymeric gel for both IPs produced. The geopolymeric gel in the IP produced using $8 \mathrm{M} \mathrm{NaOH}$ at $80{ }^{\circ} \mathrm{C}$ displayed a quite smooth surface mostly comprised of unreacted/unaffected quartz particles and an inorganic matrix (P1) containing $\mathrm{Ca}, \mathrm{Al}, \mathrm{Si}, \mathrm{Fe}, \mathrm{Mg}$ and $\mathrm{Na}$, provided from the alkaline activator or solubilised from PS. As a result of the $\mathrm{NaOH}$ solution attack in the slag, deterioration of reacted diaspore, fayalite and chromite particles is clearly observed. In addition, based on elemental analysis, several Ni-Fe sulfides grains scattered/dispersed and aggregated in the geopolymeric matrix were found containing up to $60 \% \mathrm{Ni}$. A higher magnification image of a Ni-Fe sulfide grain shown in Figure $9 \mathrm{~b}$, indicates that awaruite $\left(\mathrm{Ni}_{3} \mathrm{Fe}\right)$ occurs as inclusion along with $\mathrm{Ni}_{3} \mathrm{~S}_{2}$ within the mixed Ni-Fe sulfide matrix.

Regarding the IP produced after firing at $400{ }^{\circ} \mathrm{C}$, SEM analysis indicated a more homogenous structure filled with aggregated slag particles smaller in size $(\sim 10 \mu \mathrm{m})$ compared to the IP obtained after alkali activation with $8 \mathrm{M} \mathrm{NaOH}$ at $80^{\circ} \mathrm{C}$. This evidence is the synergistic result of alkaline solution attack along with the oxidation of PS after firing at $400{ }^{\circ} \mathrm{C}$. As seen from Figure $9 \mathrm{c}$ and in agreement with DTA/TG analysis, fayalite particles have undergone excessive oxidation and decomposition; this resulted in a compact structure filled with inclusions of inter(metallic) phases such as chromite and $\mathrm{Ni}_{3} \mathrm{~F}$. In this context, oxidation of magnetite $\left(\mathrm{Fe}_{3} \mathrm{O}_{4}\right)$ present in the PS and transformation into the stable hematite $\left(\mathrm{Fe}_{2} \mathrm{O}_{3}\right)$ is clearly visible in the IP after firing at $400{ }^{\circ} \mathrm{C}$. Figure $9 \mathrm{~d}$ (zoom of rectangular area of Figure 9c) shows in detail the oxidation of magnetite particles and the subsequent dentritic growth of hematite. 


\subsection{IP Toxicity}

Table 4 presents the toxicity of the raw PS as well as of the IPs produced after alkali activation of slag under the conditions of $\mathrm{NaOH}$ molarity $8 \mathrm{M}$, curing temperature $80^{\circ} \mathrm{C}$, curing period $24 \mathrm{~h}$, ageing period 7 days, fired at $400{ }^{\circ} \mathrm{C}$.

Table 4. EN 12457-3 results $\left(\mathrm{L} / \mathrm{S}=10 \mathrm{~L} \mathrm{~kg}^{-1}\right)$.

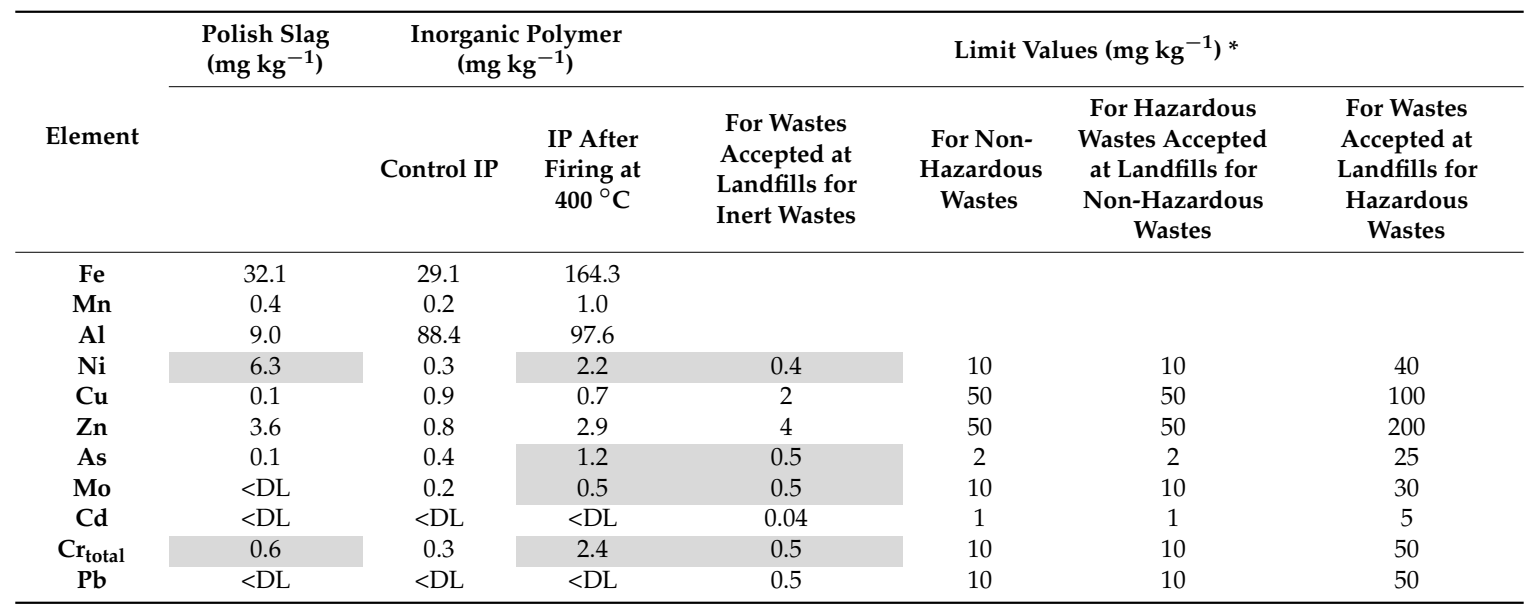

* Council Decision 19 December 2002 (2003/33/EC). Note: Shaded parts indicate elements that exceed specific limits, DL: Detection Limit.

It is seen from this data that regarding raw PS, the toxicity limits are exceeded by far only for $\mathrm{Ni}$ and slightly for total $\mathrm{Cr}$. The solubilization of these two elements is anticipated by considering the chemical and mineralogical analyses of the PS, as given by Kierczak et al. [36]. After alkali activation, the control IP produced exhibits no toxicity at all, even when the lower limits, which are specified by the EN 12457-3 test for wastes accepted at landfills for inert wastes, are taken into account. After firing the control $\mathrm{IP}$ at $400{ }^{\circ} \mathrm{C}$, the solubilisation rates of $\mathrm{Ni}$, As, total $\mathrm{Cr}$ and As increase and exceed the lower limit values indicated by this test; it is mentioned though that the indicated limit value is only marginally exceeded for As. Finally, it is mentioned that the solubilisation rates of $\mathrm{Fe}$ and $\mathrm{Al}$ increase noticeably for the IPs produced both at $80^{\circ} \mathrm{C}$ and fired at $400{ }^{\circ} \mathrm{C}$, but no limits values are specified for these two elements by the EN 12457-3 test. These results indicate the potential of alkali activation not only to contribute to the production of IPs with high compressive strength, but also to bind or trap potentially hazardous elements in a stable matrix and thus reduce their solubilization rate and overall toxicity [66].

\section{Conclusions}

The present experimental study investigated the alkali activation potential of an old Polish ferronickel slag for the production of IPs. Under the optimum synthesis conditions, namely, $\mathrm{NaOH}$ molarity $8 \mathrm{M}$, curing temperature $80^{\circ} \mathrm{C}$, pre-curing and curing time $24 \mathrm{~h}$ and ageing period seven days, the produced IPs exhibited compressive strength that exceeds $65 \mathrm{MPa}$. In this case, the molar ratio $\mathrm{SiO}_{2} / \mathrm{Na}_{2} \mathrm{O}$ of the silicate solution was equal to 0.26 , while the molar ratios $\left(\mathrm{SiO}_{2}+\mathrm{Al}_{2} \mathrm{O}_{3}\right) / \mathrm{Na}_{2} \mathrm{O}$ and $\mathrm{H}_{2} \mathrm{O} / \mathrm{Na}_{2} \mathrm{O}$ in the reactive paste were 8.6 and 12.9 , respectively. An interesting aspect of the present study is that in the reactive paste, the $\mathrm{wt} \%$ addition of $\mathrm{Na}_{2} \mathrm{SiO}_{3}$ and the overall $\mathrm{L} / \mathrm{S}$ ratio were very low, $3 \%$ and $\sim 20 \%$ respectively. This means that the IPs are produced using a cost-effective process, involving a mixture containing a high percentage of solids and limited addition of chemicals.

The main novelty of the study is the increase of the compressive strength of the IPs produced under the optimum conditions, after firing them at $400^{\circ} \mathrm{C}$ mainly as result of phase transformations and the development of a dense and compact structure filled with inclusions of inter(metallic) phases. After firing at $400{ }^{\circ} \mathrm{C}$, the IPs exhibited volumetric shrinkage of $4.8 \%$ and increased density of $2.7 \mathrm{~g} \mathrm{~cm}^{-3}$. This indicates that the produced IPs have beneficial properties and may find several applications in 
the construction sector, including their use as fire-resistant materials. The produced IPs also show very good structural integrity when immersed in water or acidic solutions for a period of 30 days. Finally, it is underlined that alkali activation results in immobilization of hazardous elements present in the raw slag and the production of IPs with very low toxicity, thus no adverse effects are anticipated from their use. The findings of this study prove that alkali activation can be used for the valorization of potentially hazardous wastes, such as metallurgical slags, and the production of high added value materials, thus improving the sustainability and minimizing the environmental impacts of the metallurgical sector.

Author Contributions: K.K.; designed the experiments, critically analyzed results, and reviewed the paper. G.B.; V.K. and E.P. performed a literature search, carried out experiments and analytical techniques, analyzed data, and wrote a first draft of the paper. W.K.; G.P. and J.K.; carried out analytical techniques for the raw materials used.

Funding: This research was funded from the European Union in the frame of Horizon 2020 project "Metal Recovery from Low-grade Ores and Wastes", www.metgrowplus.eu, Grant Agreement no 690088.

Conflicts of Interest: The authors declare no conflicts of interest.

\section{References}

1. Bai, T.; Song, Z.G.; Wu, Y.G.; Hu, X.D.; Hua, B. Influence of steel slag on the mechanical properties and curing time of metakaolin Geopolymer. Ceram. Int. 2018, 44, 15706-15713. [CrossRef]

2. Komnitsas, K.; Zaharaki, D.; Perdikatsis, V. Geopolymerisation of low calcium ferronickel slags. J. Mater. Sci. 2007, 42, 3073-3082. [CrossRef]

3. Mo, L.; Zhang, F.; Deng, M.; Jin, F.; Al-Tabbaa, A.; Wang, A. Accelerated carbonation and performance of concrete made with steel slag as binding materials and aggregates. Cem. Concr. Compos. 2017, 83, $138-145$. [CrossRef]

4. European Commission-IPPC Bureau. Reference Document on Best Available Techniques for Management of Tailings and Waste-Rock in Mining Activities; European Union: Brussels, Belgium, 2009; Available online: http:/ / eippcb.jrc.ec.europa.eu/reference/BREF/mmr_adopted_0109.pdf (accessed on 14 October 2018).

5. European Commission. Directive 2006/21/EC of the European Parliament and of the Council of 15 March 2006 on the Management of Waste from Extractive Industries and Amending Directive 2004/35/EC, Official Journal of the European Union, L 102/15-33, 11.4.2006. Available online: https://eur-lex.europa.eu/ resource.html?uri=cellar:c370006a-063e-4dc79b0552c37720740c.0005.02/DOC_1\&format=PDF (accessed on 14 October 2018).

6. Bartzas, G.; Komnitsas, K. Life cycle assessment of ferronickel production in Greece. Resour. Conserv. Recycl. 2015, 105, 113-122. [CrossRef]

7. Gee, C.; Ramsey, M.H.; Maskallh, J.; Thornton, I. Mineralogy and weathering processes in historical smelting slags and their effect on the mobilisation of lead. J. Geochem. Explor. 1997, 58, 249-257. [CrossRef]

8. Pasetto, M.; Baliello, A.; Giacomello, G.; Pasquini, E. Sustainable solutions for road pavements: A multi-scale characterization of warm mix asphalts containing steel slags. J. Clean. Prod. 2017, 166, 835-843. [CrossRef]

9. Rosales, J.; Cabrera, M.; Agrela, F. Effect of stainless steel slag waste as a replacement for cement in mortars. Mechanical and statistical study. Constr. Build. Mater. 2017, 142, 444-458. [CrossRef]

10. Davidovits, J. Geopolymers—Inorganic polymeric new materials. J. Therm. Anal. Calorim. 1991, 37, $1633-1656$. [CrossRef]

11. Davidovits, J. Chemistry of Geopolymeric Systems, Terminology. In Proceedings of the Second International Conference on Geopolymers, Saint-Quentin, France, 28-29 June 1999; pp. 9-40.

12. Duxson, P.; Provis, J.L.; Lukey, G.C.; Mallicoat, S.W.; Kriven, W.M.; van Deventer, J.S.J. Understanding the relationship between geopolymer composition, microstructure and mechanical properties. Colloids. Surf. A Physicochem. Eng. Asp. 2005, 269, 47-58. [CrossRef]

13. Kriven, W.M.; Bell, J.L.; Gordon, M. Microstructure and microchemistry of fully-reacted geopolymers and geopolymer matrix composites. Ceram. Trans. 2003, 153, 227-250.

14. Krivenko, P.V.; Kovalchuk, G.Y. Directed synthesis of alkaline aluminosilicate minerals in a geocement matrix. J. Mater. Sci. 2007, 42, 2944-2952. [CrossRef]

15. Komnitsas, K.; Zaharaki, D. Geopolymerisation: A review and prospects for the minerals industry. Miner. Eng. 2007, 20, 1261-1277. [CrossRef] 
16. Duxson, P.; Provis, J.L.; Lukey, G.C.; van Deventer, J.S.J. The role of inorganic polymer technology in the development of 'green concrete'. Cem. Concr. Res. 2007, 37, 1590-1597. [CrossRef]

17. Habert, G.; Lacaillerie, J.B.E.; Russel, N. An environmental evaluation of geopolymer based concrete production: Reviewing current research trends. J. Clean. Prod. 2011, 19, 1229-1238. [CrossRef]

18. de Toledo Pereira, D.S.; da Silva, F.J.; Porto, A.B.R.; Candido, V.S.; da Silva, A.C.R.; Filho, F.D.C.G.; Monteiro, S.N. Comparative analysis between properties and microstructures of geopolymeric concrete and portland concrete. J. Mater. Res. Technol. 2018, 7, 606-611. [CrossRef]

19. Xu, H.; Van Deventer, J.S.J. Geopolymerization of multiple minerals. Miner. Eng. 2002, 15, 1131-1139. [CrossRef]

20. Provis, J.L.; van Deventer, J.S.J. Geopolymers: Structures, Processing, Properties and Industrial Applications; Elsevier: Amsterdam, The Netherlands, 2009; ISBN 9781845694494.

21. Bernal, S.A.; de Gutierrez, R.M.; Provis, J.L.; Rose, V. Effect of silicate modulus and metakaolin incorporation on the carbonation of alkali silicate-activated slags. Cem. Concr. Res. 2010, 40, 898-907. [CrossRef]

22. Duxson, P.; Provis, J.L. Designing precursors for geopolymer cements. J. Am. Ceram. Soc. 2008, 91, 3864-3869. [CrossRef]

23. Gebregziabiher, B.S.; Thomas, R.J.; Peethamparan, S. Temperature and activator effect on early-age reaction kinetics of alkali-activated slag binders. Constr. Build. Mater. 2016, 133, 783-793. [CrossRef]

24. Khale, D.; Chaudhary, R. Mechanism of geopolymerization and factors influencing its development: A review. J. Mater. Sci. 2007, 42, 729-746. [CrossRef]

25. Yip, C.K.; Lukey, G.C.; van Deventer, J.S.J. The coexistence of geopolymeric gel and calcium silicate hydrate at the early stage of alkaline activation. Cem. Concr. Res. 2005, 35, 1688-1697. [CrossRef]

26. Nath, P.; Sarker, P.K. Effect of GGBFS on setting, workability and early strength properties of fly ash geopolymer concrete cured in ambient condition. Constr. Build. Mater. 2014, 66, 163-171. [CrossRef]

27. Wang, K.; Lemougna, P.N.; Tang, Q.; Li, W.; He, Y.; Cui, X. Low temperature depolymerization and polycondensation of a slag-based inorganic polymer. Ceram. Int. 2017, 43, 9067-9076. [CrossRef]

28. Yan, B.; Yu, Q.L.; Brouwers, H.J.H. Evaluation of slag characteristics on the reaction kinetics and mechanical properties of $\mathrm{Na}_{2} \mathrm{CO}_{3}$ activated slag. Constr. Build. Mater. 2017, 131, 334-346. [CrossRef]

29. Huang, Y.; Wang, Q.; Shi, M. Characteristics and reactivity of ferronickel slag powder. Constr. Build. Mater. 2017, 156, 773-789. [CrossRef]

30. Maragkos, I.; Gianopoulou, I.P.; Panias, D. Synthesis of ferronickel slag-based geopolymers. Miner. Eng. 2009, 22, 196-203. [CrossRef]

31. Zaharaki, D.; Galetakis, M.; Komnitsas, K. Valorization of construction and demolition (C\&D) and industrial wastes through alkali activation. Constr. Build. Mater. 2016, 121, 686-693. [CrossRef]

32. Furlani, E.; Maschio, S.; Magnan, M.; Aneggi, E.; Andreatta, F.; Lekka, M.; Lanzutti, A.; Fedrizzi, L. Synthesis and characterization of geopolymers containing blends of unprocessed steel slag and metakaolin: The role of slag particle size. Ceram. Int. 2018, 44, 5226-5232. [CrossRef]

33. Jiao, Z.; Wang, Y.; Zheng, W.; Huang, W. Effect of dosage of sodium carbonate on the strength and drying shrinkage of sodium hydroxide based alkali-activated slag paste. Constr. Build. Mater. 2018, 179, 11-24. [CrossRef]

34. Pontikes, Y.; Machiels, L.; Onisei, S.; Pandelaers, L.; Geysen, D.; Jones, P.T.; Blanpain, B. Slags with a high Al and Fe content as precursors for inorganic polymers. Appl. Clay Sci. 2013, 73, 93-102. [CrossRef]

35. Onisei, S.; Pontikes, Y.; Van Gerven, T.; Angelopoulos, G.N.; Velea, T.; Predica, V.; Moldovan, P. Synthesis of inorganic polymers using fly ash and primary lead slag. J. Hazard. Mater. 2012, 205-206, 101-110. [CrossRef]

36. Kierczak, J.; Neel, C.; Puziewicz, J.; Bril, H. The Mineralogy and weathering of slag produced by the smelting of lateritic Ni ores, Szklary, Southwestern Poland. Can. Miner. 2009, 47, 557-572. [CrossRef]

37. British Standards Institute. BS EN 1936: Natural Stone Test Methods. Determination of Real Density and Apparent Density and of Total and Open Porosity; NP EN 1936:2006; BSI: London, UK, 2007.

38. British Standards Institute. BS EN 12457-3: Characterisation of waste. Leaching. In Compliance Test for Leaching of Granular Waste Materials and Sludges. Two Stage Batch Test at a Liquid to Solid Ratio of $2 \mathrm{~L} / \mathrm{kg}$ and $8 \mathrm{~L} / \mathrm{kg}$ for Materials with a High Solid Content and with a Particle Size below $4 \mathrm{~mm}$ (without or with Size Reduction); British Standards Institue: London, UK, 2002. 
39. van der Sloot, H.A.; Hjelmar, O.; Bjerre Hansen, J.; Woitke, P.; Lepom, P.; Leschber, R.; Bartet, B.; Debrucker, N. Validation of CEN/TC 292 Leaching Tests and Eluate Analysis Methods prEN 12457 1-4, ENV 13370 and ENV 12506 in Co-Operation with CEN/TC 308; ECN: Petten, Netherlands, 2001. Available online: https:/ / publicaties.ecn. nl/PdfFetch.aspx?nr=ECN-C--01-117 (accessed on 9 November 2018).

40. European Commission (EC). Council Decision 2003/33/EC of 19 December 2002 Establishing Criteria and Procedures for the Acceptance of Waste at Landfills Pursuant to Article 16 of and Annex II to Directive 1999/31/EC; European Commission: Brussels, Belgium, 2003. Available online: https://eur-lex.europa.eu/legalcontent/ EN/TXT/PDF/?uri=CELEX:32003D0033\&from=EN (accessed on 9 November 2018).

41. Komnitsas, K.; Zaharaki, D.; Perdikatsis, V. Effect of synthesis parameters on the compressive strength of low-calcium ferronickel slag inorganic polymers. J. Hazard. Mater. 2009, 161, 760-768. [CrossRef] [PubMed]

42. Azevedo, A.G.D.S.; Strecker, K. Brazilian fly ash based inorganic polymers production using different alkali activator solutions. Ceram. Int. 2017, 43, 9012-9018. [CrossRef]

43. Komnitsas, K.; Zaharaki, D.; Vlachou, A.; Bartzas, G.; Galetakis, M. Effect of synthesis parameters on the quality of construction and demolition wastes (CDW) geopolymers. Adv. Powder Technol. 2015, 26, 368-376. [CrossRef]

44. Kaze, C.R.; Djobo, J.N.Y.; Nana, A.; Tchakoute, H.K.; Kamseu, E.; Melo, U.C.; Leonelli, C.; Rahier, H. Effect of silicate modulus on the setting, mechanical strength and microstructure of iron-rich aluminosilicate (laterite) based-geopolymer cured at room temperature. Ceram. Int. 2018, 44, 21442-21450. [CrossRef]

45. Peys, A.; White, C.E.; Olds, D.; Rahier, H.; Blanpain, B.; Pontikes, Y. Molecular structure of $\mathrm{CaO}-\mathrm{FeO}_{\mathrm{x}}-\mathrm{SiO}_{2}$ glassy slags and resultant inorganic polymer binders. J. Am. Ceram. Soc. 2018, 101, 5846-5857. [CrossRef]

46. Onisei, S.; Douvalis, A.P.; Malfliet, A.; Arne Peys, A.; Pontikes, Y. Inorganic polymers made of fayalite slag: On the microstructure and behavior of Fe. J. Am. Ceram. Soc. 2018, 101, 2245-2257. [CrossRef]

47. Lemougna, P.N.; Chinje Melo, U.F.; Delplancke, M.-P.; Rahier, H. Influence of the activating solution composition on the stability and thermo-mechanical properties of inorganic polymers (geopolymers) from volcanic ash. Constr. Build. Mater. 2013, 48, 278-286. [CrossRef]

48. Onisei, S.; Malfliet, A.; Gutierrez-Campos, D.; Blanplain, B. Synthesis and high temperature transformations of Fe-rich inorganic polymers. In Proceedings of the 4th International Slag Valorization Symposium, Leuven, Belgium, 15-17 April 2015; Malfliet, A., Pontikes, Y., Eds.; pp. 243-248. Available online: http:/ /www.slagvalorisation-symposium.eu/2015/images/papers/SVS2015-Onisei.pdf (accessed on 21 November 2018).

49. Zaharaki, D.; Komnitsas, K.; Perdikatsis, V. Use of analytical techniques for identification of inorganic polymer gel composition. J. Mater. Sci. 2010, 45, 2715-2724. [CrossRef]

50. Zaharaki, D.; Komnitsas, K. Long term behaviour of ferronickel slag inorganic polymers in various environments. Fresenius Environ. Bull. 2012, 21, 2436-2440.

51. Marangoni, M.; Arnout, L.; Machiels, L.; Pandelaers, L.; Bernardo, E.; Colombo, P.; Pontikes, Y.; Jantzen, C. Porous, sintered glass-ceramics from inorganic polymers based on fayalite slag. J. Am. Ceram. Soc. 2016, 99, 1985-1991. [CrossRef]

52. Rincón, A.; Desideri, D.; Bernardo, E. Functional glass-ceramic foams from 'inorganic gel casting' and sintering of glass/slag mixtures. J. Clean. Prod. 2018, 187, 250-256. [CrossRef]

53. Nazer, A.; Payá, J.; Borrachero, M.V.; Monzó, J. Use of ancient copper slags in Portland cement and alkali activated cement matrices. J. Environ. Manag. 2016, 167, 115-123. [CrossRef] [PubMed]

54. Zong, Y.; Zhang, X.; Mukiza, E.; Xu, X.; Li, F. Effect of Fly Ash on the Properties of Ceramics Prepared from Steel Slag. Appl. Sci. 2018, 8, 1187. [CrossRef]

55. Bakharev, T. Geopolymeric materials prepared using class F fly ash and elevated temperature curing. Cem. Concr. Res. 2005, 35, 1224-1232. [CrossRef]

56. Yang, Z.; Lin, Q.; Lu, S.; He, Y.; Liao, G.; Ke, Y. Effect of $\mathrm{CaO} / \mathrm{SiO}_{2}$ ratio on the preparation and crystallization of glass-ceramics from copper slag. Ceram. Int. 2014, 40, 7297-7305. [CrossRef]

57. Komnitsas, K.; Petrakis, E.; Bartzas, G.; Karmali, V. Column leaching of low-grade saprolitic laterites and valorization of leaching residues. Sci. Total Environ. 2019, 665, 347-357. [CrossRef] [PubMed]

58. Mužek, M.N.; Zelić, J.; Jozić, D. Microstructural characteristics of geopolymers based on alkali-activated fly ash. Chem. Biochem. Eng. Q. 2012, 26, 89-95. Available online: http://pierre.fkit.hr/hdki/cabeq/pdf/26_2_ 2012/Cabeq\%202012-02_3.pdf (accessed on 24 November 2018).

59. Liu, Y.; Zhang, K.; Feng, E.; Zhao, H.; Liu, F. Synthesis of geopolymer composites from a mixture of ferronickel slag and fly ash. IOP Conf. Ser. Mater. Sci. Eng. 2017, 182, 012038. [CrossRef] 
60. Bernal, S.A.; Rodríguez, E.D.; de Gutiérrez, R.M.; Provis, J.L. Performance at high temperature of alkali-activated slag pastes produced with silica fume and rice husk ash based activators. Mater. Constr. 2015, 65, e049. [CrossRef]

61. Palomo, A.; Grutzeck, M.W.; Blanco, M.T. Alkali-activated fly ashes: A cement for the future. Cem. Concr. Res. 1999, 29, 1323-1329. [CrossRef]

62. Bakri, A.M.M.A.; Kamarudin, H.; Bnhussain, M.; Ismail, K.N.; Yahya, Z.; Razak, R.A. Fly Ash-based Geopolymer Lightweight Concrete Using Foaming Agent. Int. J. Mol. Sci. 2012, 13, 7186-7198. [CrossRef]

63. Gyurov, S.; Marinkov, N.; Kostova, Y.; Rabadjieva, D.; Kovacheva, D.; Tzvetkova, C.; Gentscheva, G.; Ivan Penkov, I. Technological scheme for copper slag processing. Int. J. Miner. Process. 2017, 158, 1-7. [CrossRef]

64. Mihailova, I.; Radev, L.; Mehandjie, D. Phase composition, structure and catalytic activity in oxidation reactions of fayalite waste from the flotation of copper slag. J. Chem. Technol. Metall. 2017, 52, 929-939. Available online: https://dl.uctm.edu/journal/node/j2017-5/17_17-69_Irena_p_929-939.pdf (accessed on 14 December 2018).

65. Zuo, Z.; Yu, Q.; Wei, M.; Xie, H.; Duan, W.; Wang, K.; Qin, Q. Thermogravimetric study of the reduction of copper slag by biomass. Therm. Anal. Calorim. 2016, 126, 481. [CrossRef]

66. Komnitsas, K.; Zaharaki, D.; Bartzas, G. Effect of sulphate and nitrate anions on heavy metal immobilisation in ferronickel slag geopolymers. Appl. Clay Sci. 2013, 73, 103-109. [CrossRef]

(C) 2019 by the authors. Licensee MDPI, Basel, Switzerland. This article is an open access article distributed under the terms and conditions of the Creative Commons Attribution (CC BY) license (http://creativecommons.org/licenses/by/4.0/). 